\title{
Theory of language: a taxonomy
}

\author{
Patrik Austin ${ }^{1}$ (D)
}

Received: 6 September 2020 / Accepted: 12 February 2021 / Published online: 9 March 2021

(c) The Author(s) 2021

\begin{abstract}
The study of language has been historically proposed as a model for human sciences. For the structuralists, it is because languages, like society, and cultural habits, are man-made rule-based systems. For the Darwinists, it is because cultures and societies are like living species, and can be studied with biological methodology. Sociology, biology and linguistics are considered analogous in different ways. To support work in theoretical and applied linguistics, this paper discusses the problem of the nature of language, investigating how the question "What is language?" has been approached from different angles. Textbook answers guide us in many different directions: language is a tool for communication-and for thinking. It is a collection of words and instructions how to use them. It is the characteristic which-arguably-separates humans from other animals. It is a social construction, a system of symbols, a system of systems, and so on. To classify perspectives, the intellectual history of schools of linguistic thought is examined, connecting linguistic theory with related disciplines. A taxonomy is proposed based on two axes: humanistic versus biological; and historical versus systemic. Main linguistics frameworks are identified and placed into a fourfold table based on these axes. They include the Bloomfieldian school (Type 1); Saussurean structuralism and its derivatives (Type 2); generative grammar and biolinguistics (Type 3); and cognitive-evolutionary linguistics (Type 4).
\end{abstract}

Keywords Theoretical linguistics · Nature of language · Philosophy of linguistics · Essence of language $\cdot$ Linguistic theories $\cdot$ History of linguistics

\section{Introduction}

What is language? Mainstream linguists of a given time tend to approach the question by an appeal to scientific progress. A typical account may start by stating that modern linguistics begins in Ferdinand de Saussure's ([1916] 1959) Course in

Patrik Austin

Patrik.Austin@Helsinki.fi

1 Department of Modern Languages, University of Helsinki, Helsinki, Finland 
Linguistics which considers language-la langue - a set of social rules. This understanding was improved by Noam Chomsky who made the correction that the proper term is linguistic competence, and that rules are based on an innate structure or mechanism (Chomsky 1965). However, twenty-first century cognitive linguists realised this was a mistake: there are no 'rules'; language is an organism (MacWhinney and O'Grady 2015).

Curiously, historical sources teach us that this most modern understanding of language had been rejected by sociologist Georg Simmel by 1890 (Klautke 2010), and seriously questioned and reformed by William Dwight Whitney (1875) and the neogrammarians on whose work Saussure (ibid., p. 5) built his theory. If we take the linguist's word, then, the evolution of the field seems to have been perfectly cyclic.

That is why this paper considers the language problem to be a philosophical one. By this, it is meant that it involves certain principles which are theoretical in their essence rather than just scientific; and that such principles are of a timeless nature. There might never be a single solution to the philosophical language problem: what has been perceived as progress could be fundamentally a question of indecision between the kinds of aspects which could have been established by the intellectual caveperson. Indeed, many early philosophical treatises of the nature and origin of language are found in surviving folk myths from around the world.

Notwithstanding, the focus of this paper as a taxonomy of linguistic thought looks at the question from a pragmatic side, laying down the ideas that, after some thousands of years of philosophical thought on language, have proved to be as fundamental as they are divisive for the modern schools of linguistic analysis. Therefore they form the often-implicit basis of academic research and training in the many fields of science that are related to linguistics.

Schools of linguistics are enumerated by Sampson (1980) who concludes that further groupings will be difficult to make, but predicts that future linguistics will be dominated by biology. Subsequent attempts at a tighter generalisations include Scholz et al.'s (2020) and Nichol's (1984) tripartite taxonomies; while Croft (1995, 2015) proposes a binary model.

\section{A search in history for the axes of theories of language}

A common starting point for the debate about the nature of language is found in Plato's dialogue Cratylus where Socrates raises the question whether word forms are arbitrary or iconic, to use modern terminology. Socrates concludes that they can be either, so the philosopher should rather direct their inquiry to what would become to be known as the Platonic forms (Cooper and Hutchinson 1997).

There is not quite enough substance for a nature-nurture debate because these philosophers seem to have considered it rather obvious that language is man-made. The view arising from Cratylus is that there are some who possess the craft of wordmaking, but the acceptance of words depends on the language users.

This view was confronted by Christian theology which took the Bible as the foundation of knowledge of the universe in the Middle Ages. It was generally thought 
that all languages are derived from the one that God used to talk to Adam. Therefore, language is part of the Creation (Jermołowicz 2003).

On the fringes of Christian influence, however, Al-Farabi (ca. 870-ca. 950) elaborates the nature of social and societal construction of language as follows. People first realise that they can communicate their needs better if they agree to label some objects and concepts with simple vocal sounds. These are later compounded to create more words. Eventually lawmakers will regulate language usage for the benefit of the community (Druart 2019).

The Age of Enlightenment saw humanistic thinking as applied to philosophy of language, with new interpretations of the Holy Scripture which emphasise Man's active role in the creation of his own cultural habits. George Dalgarno ([1661] 1974) pointed out that, in the Genesis, Adam names the animals, suggesting that modern languages are man-made. Port-Royal Grammar (Arnauld and Lancelot [1660] 2015) crystallises the Age of Reason thesis by explaining that God created Man rational and social. Therefore, Man used his intelligence to construct language in order to communicate his thoughts to others.

Theological thinking gradually gave way to the modern humanism of the nineteenth century, but naturalistic thinking about culture makes a remarkable return revolutionised by natural selection theory, and later as consolidated by Mendelian genetics. Social Darwinists looked for ways to adopt linguistics to evolutionary biology. Charles Darwin (1871) suggested that human languages are derived from animal mating calls. August Schleicher ([1863] 1869) considered languages as species in a struggle for existence, and argued that linguistics belongs to life sciences. This enterprise continues today (Type 3 and Type 4) giving us our primary axis: humanistic versus biological approaches to theory of language.

A secondary axis comes from the separation of a historical from a systemic view. The concept of historical explanation is of course old, with examples of etymological speculations also found in Cratylus, while the Genesis provides an early treatise of the origin and geographic spread of languages.

Mythological explanation is gradually removed from evolutionary hypotheses. Spurred by the Industrial Revolution and growing interest in archaeology, social organisation comes to be defined in terms of historical progress guided by a collective spirit by Georg W. F. Hegel (1807) and his contemporaries.

The modern worldview also influenced nineteenth century linguistic research which undertook several big projects: etymologies, genealogical studies, and the reconstruction of the Proto-Indo-European language with a historical-comparative method. While there may have been naïve hopes of uncovering the lost fountainhead of human language, Saussure and his followers acknowledged the ultimate impossibility of gaining reliable knowledge of unrecorded extinct languages (Aronoff 2017).

Saussure's solution was to limit the explanatory role of the diachronic approach (Aronoff 2017, p. 212) and to investigate systemic cohesion to gain understanding of why the known languages are the way they are. Structural linguistics as it later became called-Saussure called his approach semiology-is the study of the inner workings of language as a bilateral system of meaning and expression (Dosse 1997a). 


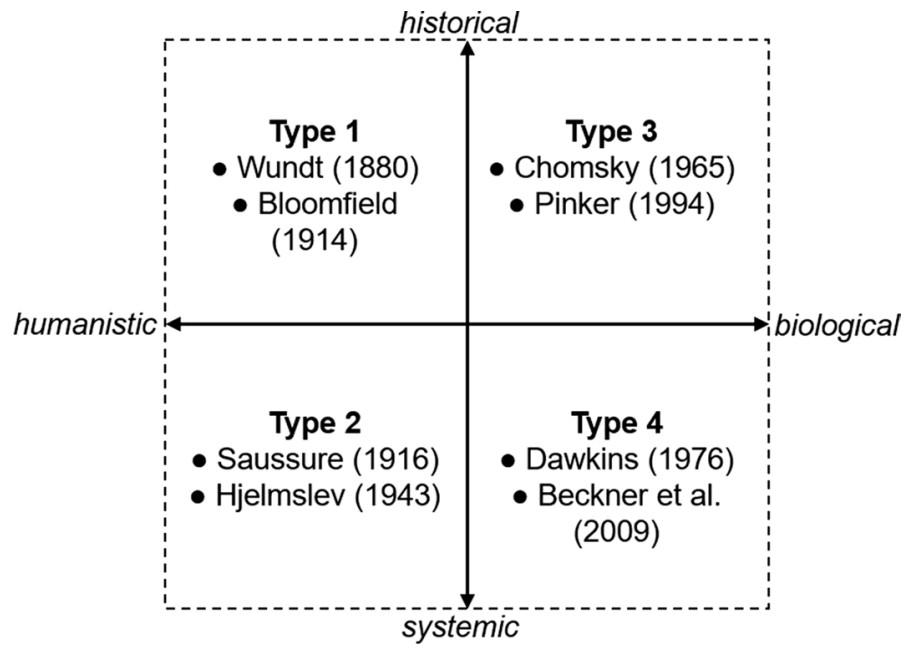

Fig. 1 Theory of language: a fourfold table made up of the vertical axis humanistic versus biological; and the horizontal axis historical versus systemic. Influential works are cited within each type. Type 1 (see "Type 1: humanistic-historical" section) approach is humanistic-historical; Type 2 ("Type 2: humanistic-systemic" section) is humanistic-systemic. Type 3 ("Type 3: Biological-historical" section) represents a biological-historical theory of language; and, Type 4 ("Type 4: Biological-systemic" section), a biological-systemic theory

Systemic explanation is of course not completely new, either. Early grammars, including Pāṇini's Ancient Sanskrit grammar, treat language as a rulebased system (Kiparsky 2009). Thomas of Erfurt's mediaeval Modistae grammar is an early example of an attempt to define word classes and sentence parts in opposition to one another (Seuren 1998). The foundation of this method is traced back to the grammar of the Stoics, and, ultimately, to Plato's writings and to Aristotelian syllogism (Itkonen 2013b).

A systemic view of social organisation can also be of a biological kind. It is a rather obvious realisation that human society in some ways resembles an organism or the nests of social insects, with members of society carrying out different vital functions. One instance of this metaphor is Bernard Mandeville's (1705) satirical poem The Grumbling Hive. The Stoics, on the other hand, had likened philosophy to a living animal: with logic as the bones, ethics as the flesh, and physics as the soul (Long 1982); Thomas Hobbes's ([1651] 2010) Leviathan depicts society as a body consisting of its citizens; while Herbert Spencer (1820-1903) likened society to a complex of organs with different functions (Corning 1982).

Admittedly, the view of language as an organic system appears to be relatively recent. A language-organism analogy was used by Franz Bopp (1816; Lehmann 2016) and, following the success of Charles Darwin's Origin of the Species (1859), it was converted to a scientific claim by August Schleicher (ibid.). This 
was in turn reformed as the idea of language as a population of words by Müller (1870).

Hereby the two axes: humanistic-biological, and historical-systemic, form a fourfold table in our taxonomy (Fig. 1).

\section{Humanistic linguistics}

Humanistic linguistics is used as an umbrella term for approaches which regard language as a human invention, separating the subject matter from the sphere of biological inquiry (Itkonen 2011; see also Daneš 1987, p. 30). In this view, linguistics can primarily be seen as a social, historical and psychological discipline (Type 1); or as semiotics: the study of systems of signs and sign processes (Type 2).

\section{Type 1: humanistic-historical}

The first square in the fourfold table regards languages as the products of sociocultural evolution. When we ask why a certain language is the way it is, the standard answer is that its forms have taken shape with the history of the nation who speaks it. As concerns linguistic universals, it could be the case that similarities between unrelated languages have been exaggerated due to an overly Eurocentric perspective; or that social development and information make people think more logically, and since there is only one logic or reason, languages will share certain structures.

As discussed above, evolutionary thinking about culture had become the dominant paradigm by the nineteenth century; although similar ideas had been discussed by earlier philosophers such as Epicurus (341 BCE-270 BCE; see Verlinsky 2005) and Giambattista Vico (1668-1744; Danesi 1993).

Although in many cases ideas proposed by theorists of sociocultural evolution may appear suspiciously similar to those presented by evolutionary biologists, there are reasons why the humanistic and the sociobiological framework should not be confused. For example, Wilhelm Wundt explains the difference between biology and the cultural perspective of Völkerpsychologie:

[T]o the natural sciences belong all those disciplines in whose exploration facts are studied without regard to the participation of a thinking and purposeful agent, while to the mental sciences belong all those subjects in which facts are studied whose existence depends essentially on such a subject. (Wundt 1889: 33; cited through Macnamara 2009: 205)

The most common evolutionary approach is the stadial theory which proposes that human societies progress through stages that are predetermined to some degree. The basic idea is that certain innovations are prerequisite to others, so progress takes place in causal steps (Wolloch 2011).

There are different opinions of how languages have evolved. While some argued for linear progress: from primitive to logical; others highlighted the purity of the 
classical languages, followed by a decay in their modern forms; but the Renaissance had also sparked the appreciation and establishment of national languages as the new expressive means of literature and science (Nichols 2012).

One to argue against artificial refinement of the national language by scholarly grammarians was Jacob Grimm (1785-1863) who regarded language as a natural social phenomenon-Sprachgeist-and language change as occurring along fixed patterns which are governed by mechanical sound laws. Franz Bopp (1791-1867) considered linguistics as the study of the structures of the Geist, or social organism, developing the historical-comparative method which connects the etymologies of different languages. In Bopp's conception, the essence of language is uncovered through the investigation of its life and growth (Pourciau 2017).

At this time, sociology was still to establish itself as a scientific discipline: during the nineteenth century, social matters were considered as belonging to the sphere of psychological inquiry (Hejl 1995). Society, then, has its own psyche that requires an examination. It is Volksgeist: the spirit or genius of the nation that stores collective cultural knowledge (Verheggen 1996).

Moritz Lazarus (1824-1903) and Heymann Steinthal (1823-1899) coined the term Völkerpsychologie: the study of the myths, customs and the language of the nation. Of the nation psychologists, Wilhelm Wundt (1832-1920) became the most influential, and his ideas were imported to America by Franz Boas (1858-1942) who founded the modern Boasian school of anthropology (Klautke 2010); and Leonard Bloomfield (1887-1949) who founded the Bloomfieldian school of linguistics which was later nicknamed 'American structuralism' (Joseph 2002). Here, the word structuralism has a different reference from the movement in humanities generally referred to as structuralism (cf. Type 2).

Wundt's interest in nation psychology lay in its potential to explain the mind structures of the individual. His model of psychological evolution involved four stages, from the irregular patterning of the primitive mind all the way to the highly civilised mind where everything is organised into binary branching structures. Wundt's corresponding linguistic model is identical with the universal grammar of the Modistae (Seuren 1998), deriving from the logical grammar of the Stoics (Itkonen 2013b).

Boas agreed with Wundt's nation psychology, but removed his stages of social and psychological evolution to emphasise that all nations are equally good at catering for the needs of their members (Klautke 2010). He advocated particularism which remained the norm in anthropology until the 1960s (Spiro 1986).

Bloomfield in his turn was particularly interested in Wundt's account of the logical or philosophical grammar (Seuren 2006). Nation psychology eventually became strongly associated with German nationalism (Klautke 2010), and after World War I, Bloomfield's (1914) endorsement of it became unsustainable (Joseph 2002). Bloomfield then wrote a new textbook of linguistics which endorsed the behavioural psychology of A. P. Weiss (Bloomfield 1933), although, importantly, his linguistic analysis remained loyal to Wundt's structural psychology (Seuren 2006). The idea from German romanticism, that language shapes the worldview of the individual, eventually became known as the 'Sapir-Whorf hypothesis' (Koerner 1992). 
The post-Bloomfieldian school failed to establish a scientific justification for the binary-branching structure (cf. Wells 1947; Seuren 1998) which became challenged by the European structuralists who proposed a semantic analysis of syntax (Garvin 1954; Osborne and Kahane 2015). Noam Chomsky eventually solved the problem by claiming that syntax is innate, leading mainstream American linguistics across the nurture-nature divide (see Type 3).

Nonetheless, the sociocultural-evolutionary mode of explanation has survived well in the fields of historical linguistics (Evans and Bowern 2015) and anthropological linguistics (McElhinny 2015), and there have even been some signs of renewed general interest. Critical reception of Dan Everett's Language: The Cultural Tool (Everett 2012) echoes nineteenth century reactions to Volksgeist thinking:

[U]sing Everett's reasoning, we would notice phrases like English West Wing and speculate that we English-speakers conceptualize our buildings as giant flying birds; or we might take the phrase downtown branch in relation to a bank to suggest that in English-speaking culture, we conceptualize institutions as giant trees[.] (Enfield 2013: 161)

Everett had actually suggested that the fact that the Amazonian Wari language has the same word for wife and vagina raises "an obvious cultural question". However, gender issues in language are quite seriously discussed by modern feminist thinkers (Ehrlich et al. 2014), and the way culture shapes people's thinking is a core problem in the overall post-structuralist movement (Williams 2005). Although any explanation can be taken too far, undoubtedly, there remain valid points for future research to be made about the connection between the histories and languages of nations, and how these affect the individual's understanding of the world.

\section{Type 2: humanistic-systemic}

This section looks into the development of a view of language as a system in its own right. A precursor to a systemic view of language is found in Wilhelm von Humboldt (1767-1835). Although a proponent of Type-1 linguistic relativity (Koerner 1978), Humboldt preferred a different type of comparative linguistics—crosslinguistic comparisons, today called typology — to gain insight into universal features of the world's languages. He also laid the foundation for the modern notion of phonology as the study of the sound systems of languages. Humboldt furthermore envisaged a linguistics as guided by a universal matrix of inventories of common elements, rules and structures to help scholars gain access to any language (Humboldt 1836; Mueller-Vollmer and Messling 2017).

Towards the end of the nineteenth century when great etymological projects were nearing their completion, the limitations of the historical-comparative method became painfully evident to linguists like Saussure owing to the insufficiency of all available written sources (Aronoff 2017). Saussure then proposed laying emphasis on synchronic analysis as an alternative route to understanding why, ultimately, languages are the way they are (Saussure [1916] 1959, pp. 212-214; Aronoff 2017, p. 450). 
In Saussure's conception, language is a semiotic system which is made of bilateral signs, or expression-meaning pairings. Following a long line in humanistic thinking - whether rationalist or empiricist - the expressive plane, the conceptual plane and the linkage between the two are all organised according to arbitrary rules of social convention. From this, however, Saussure draws an original conclusion (Nöth 1995).

Because the bilateral sign system lacks a non-conventional foundation in both of its aspects, it is neither anchored in reality nor in personal psychology. Instead, linguistic organisation arises purely from the association of expression and meaning: there is no expression without meaning, and no meaning without expression (Saussure, ibid., pp. 7-17).

Saussure regards language as a 'social fact' - something which resembles the nation spirit (Klautke 2010)_but, at the same time, it is a kind of geometrical system where all elements are defined in relation to each other in complex networks. Saussure's realisation that society contains many such systems became a core tenet of the post-war structuralist movement which then developed into various frameworks of post-structuralism (Dosse 1997a, b). Thus, Saussure would unwittingly become one of the most influential thinkers of the twentieth century.

Saussure also proposes a semantic and functional analysis of grammar. His own work is still heavily focused on etymology, with more pages dedicated to diachronic than synchronic linguistics (Saussure [1916] 1959). Further methods of structural linguistics would be developed by others. Following a shift from structural to functional explanation in sociology in the 1920s, the Prague linguistic circle lays the foundation of functional linguistics based on Saussure's bilateral sign, but also as investigating how the role of language as a tool for communication affects its forms (Daneš 1987).

French functionalist André Martinet elaborates the concept of economy, a compromise between simplicity and clarity, as a force which controls language change (Vicentini 2003). His linguistic analyses also influenced Jacques Derrida's ([1967] 1998) philosophy.

Danish linguist Louis Hjelmslev takes a different path from Saussure. Based on the algebraic grammars of mathematicians, he proposes glossematics - the analysis of each linguistic element from smallest to largest on both the expressive and the conceptual plane - to gain insight into the compositional nature of language (Seuren 1998). Hjelmslev points out that this method also makes it possible to generate all grammatical productions of a given language, and that the method actuates recursion which allows an infinite number of grammatical productions (Hjelmslev [1943] 1953):

When we compare the inventories yielded at the various stages of the deduction, their size will usually turn out to decrease as the procedure goes on. If the text is unrestricted, i.e., capable of being prolonged through constant addition of further parts [...] it will be possible to register an unrestricted number of sentences[.] (Hjelmslev [1943] 1953: 26)

Hjelmslev considers such calculus primarily non-biological, non-psychological and non-sociological. Thus, he regards "language itself" as a kind of abstract object. 
Similarly to Humboldt, Hjelmslev proposes that the method be used to analyse and compare the structures of all languages to learn to understand their ways. Like Saussure, Hjelmslev's model became highly influential in semiotics (Nöth 1995), and his theory of linguistic analysis was put into practice by the subsequent programmes of functional grammar which continue today (Butler 2003).

Another syntactician who should be mentioned is Lucien Tesnière who took his influences from Humboldt and Otto Jespersen rather than from Saussure's interactive model: Tesnière's analysis assumes the primacy of semantics in language. Opposing philosophical or logical grammar (see "Type 1: humanistic-historical" section), Tesnière created a non-phrasal dependency analysis which has later found its applications in computer linguistics as a more elastic alternative to generative grammar (Osborne and Kahane 2015).

\section{Sociobiological or Darwinian evolutionary linguistics}

"Type 3: Biological-historical" and "Type 4: Biological-systemic" sections will present biological or sociobiological approaches to linguistic theory. Type 3 represents what is described as sociobiology (the evolutionary study of behaviour) or evolutionary psychology (the evolutionary study of psychological traits; Croft 2006: 91). Type 4 is also described by Croft (2006, p. 6) as ultimately biological; however, the foundation of linguistic explanation of this type is not considered genetic, but indirectly biological and based on evolutionary theory (cf. Croft 2000).

Evolution is somewhat ambiguous as a term and has been used by different schools on both sides of the nature-nurture divide. To summarise differences ("A search in history for the axes of theories of language" and "Type 1: humanistic-historical" sections), the classical approach to sociocultural evolution explains change by means of stadial development or progress. For example, the chronological order of technological advancement from Stone Age to Iron Age through Bronze Age can be regarded as predetermined because stone tools were prerequisites of bronze metallurgy, and bronze tools were prerequisites of iron metallurgy (Johnston 1922).

However, due to its success in providing a solution for functional explanation in biology, Darwin's principle of natural selection has later on become near-synonymous with evolutionary theory. It is today not so commonly known that Darwin intended natural selection to be applied to cultural evolution, too (Darwin 1871); or that his theory had many now-forgotten rivals, some explicitly anti-Darwinian, until mid-twentieth century (Popov 2008).

Fundamental ideological differences lie in the causation. The humanistic viewpoint regards language as an intelligent social creation. According to biologism, in contrast, it emerges involuntarily via evolutionary biological mechanisms (Itkonen 1999, 2011, 2013a).

The natural paradigm with its tendencies, sociobiological or evolutionary-biological, denotes here the kind of schools of evolutionary linguistics which adopt the Darwinian or neo-Darwinist view of evolution. A special case is the Chomskyan concept of language based on evolutionary biological mechanisms, albeit not on adaptation or evolutionary stages. It is included in the Darwinian, natural and 
sociobiological paradigm (cf. Chomsky and McGilvray 2012, pp. 104-107; Fitch 2010, pp. 20-21).

"Type 3: Biological-historical" section (Type 3) will give an overview of language as caused by human genes, and "Type 4: Biological-systemic" section (Type 4) will present frameworks which link linguistics with the study of living organisms.

\section{Type 3: Biological-historical}

Square 3 in our taxonomy explains language from a historical and evolutionary biological perspective. Charles Darwin (1871) hypothesised that human languages have evolved from animal mating calls. One way to build on biology is via the addition of Mendelian genetics to Darwin's model of natural selection. Genetic determinism is the idea that people are born with genes that generate sociocultural behaviour including language (P. Ehrlich and Feldman 2003).

Evolutionary psychologist Steven Pinker (1994) argues that the human language faculty has evolved through an interplay of genetics and natural selection, thus bringing about a language instinct in humans. This instinct entails an innate "universal grammar"; an idea which comes from Chomsky who however argues that it has been caused by a single mutation. As Chomsky (2000) illustrates,

To tell a fairy story about it, it is almost as if there was some higher primate wandering around a long time ago and some random mutation took place, maybe after some strange cosmic ray shower, and it reorganized the brain, implanting a language organ in an otherwise primate brain. (Chomsky 2000: 4)

The language organ is hypothesised to contain universal grammar which has the same binary-branching structure as Wundt's psychological grammar ${ }^{1}$ (Seuren 1998; Joseph 2002; cf. Berwick and Chomsky 2016, pp. 10-11). Therefore it seems simplest to regard Chomsky's generative grammar a sociobiological transformation of the Wundtian model (Type 1). In Chomsky's conception, however, the mind is structured into various autonomous modules such as language, ethics, and mathematics. According to this claim, language (i.e. universal grammar) cannot be learned by deduction, but only acquired from the language organ (Smith 2002).

Since the 1960s Chomsky has made many attempts to link his theory to early humanist thinkers, sparking negative reactions from experts of Humboldt, Descartes, Arnauld, and others; it is more lately suggested that Chomsky's theory lacks a pedigree in philosophy (Hamans and Seuren 2010).

\footnotetext{
1 Note that the terms logical grammar, philosophical grammar, psychological grammar; and also the Stoic grammar, and the universal grammar of Thomas of Erfurt or the Modistae, all refer to the idea that the sentence is divided into the subject and the predicate (or verb phrase as it is called in the generative and modern context). This Ancient practice became challenged by twentieth century analyses which are purely based on semantics whereby the subject and the object are considered as equal constituents (Seuren 1998; Halliday and Matthiessen 2014, p. 151f; Osborne and Kahane 2015).
} 
Although referred to as rationalism, it is worthwhile to briefly discuss why Chomsky's claim of representing "Cartesian linguistics" has been disputed. Chomsky does not consider language as a human rational creation at all, so his interest is purely in Descartes's concept of innate ideas. Chomsky's universal grammar, however, is a dependency structure, so it does not contain any innate ideas. As such, Chomsky's theory does not seem to be directly related to the philosophical mode of explanation called rationalism (Markie 2017).

In the context of cognitive science, Chomsky's generative grammar is contrasted with George Lakoff's 'empiricism', which also calls for a brief comment. According to Lakoff, people have inherited from lower animals the ability to make rational judgments based on visual thinking (Lakoff 1990). Knowledge is embodied in the sense that it is categorised by sensory modalities. Thus, antithetically to innate grammar, Lakoff's cognitive linguistics investigates how language emerges from sensory metaphors, e.g. a warm smile; a close friend (Lakoff and Johnson 1999).

For the explanation mode known as empiricism, senses are a requirement of experience; but it seems this version of cognitive linguistics considers the senses as being of primary interest themselves. Some associate Lakoff's idea with an applied psychological movement called neuro-linguistic programming which teaches people-influencing techniques (Feldman 2007; Mathison and Tosey 2009).

Biological approaches to language attempt to make scientific rather than metaphysical statements, which is desirable in principle. So far such research programmes have not been completely successful in establishing biological linguistics as a proper natural science. There is to date no evidence for an innate language structure. The claims of Pinker and Chomsky were discredited by the mainstream language acquisition and psycholinguistics research community around 2000 (Fernald and Marchman 2006; de Bot 2015). For some, the question is today which way biolinguistics should turn next.

Dual inheritance theory or the study of co-evolution of language and culture is proposed as a more sustainable approach (Koster 2009; Richerson and Boyd 2010). The question remains to what extent it can provide a useful alternative to generative linguistics because the human genome does not evolve hand in hand with linguistic change. While it is uncontroversial that the human body provides many features which are useful for vocal communication, there is no direct indication that human anatomy generates grammar, apparently leaving the core aspects of language to culture (cf. Type 1 and 2).

Another way to go is to argue for a more indirect effect of genes, as exemplified by Lakoff's non-generative concept above. Lakoff and his colleagues have however broken away from Type 3 to develop an overarching Type 4 theory (see next subsection).

Hawkins's (2004) performance-grammar hypothesis suggests that certain structures could be the manifestations of processing preferences of the human brain, thus explaining why typological comparisons indicate statistical tendencies rather than absolute universals in the languages of the world. Currently, though, this hypothesis is yet to be verified by psycholinguistic research (Song 2010, pp. 278-279). 


\section{Type 4: Biological-systemic}

Type 4 regards language as an organism or a population. As regards the systemic aspect of language, it is worthwhile to mention that both Type 2 (humanistic-systemic) and Type 4 (biological-systemic) emerged from 19th-century historical linguistics. The biological type came first, introduced by August Schleicher (1821-1868) who was an Indo-Europeanist-like Saussure-but also an expert on botany and gardening. Inspired by Bopp's historical organicism and, later, Darwin's (1859) Origin of the Species, Schleicher essentially synthesised his fields of knowledge into a single science. Through his historical-comparative research Schleicher came to view languages as biotic entities which grow, spread beyond their territory, have offspring, and eventually die (Koerner 1978; Aronoff 2017).

The Type 4 systemic conception of linguistic theory is essentially different from Type 2 'structuralism' which grew out of Saussure's rejection of Schleicher and his associates (Saussure [1916] 1959, pp. 3-5 et passim). Unlike Saussure, Type 4 authors do not generally consider language as arising from mechanisms of meaning such as opposition or symmetry (see e.g. Croft 1995). Saussure (ibid., pp. 7-15) for his part objected to Schleicher, arguing that the language organism has no evolution of its own because language and its changes are only products of the speech community $^{2}$ (cf. also Type 1).

This argument has again been rejected by today's Type 4 evolutionary linguists who study the evolution of language as a phenomenon of its own kind. Language is considered as a system which adapts to its ecological environment. As mentioned in "Type 3: Biological-historical" section, Lakoff's Cognitive Linguistics is linked with the non-innate evolutionary framework (Croft 2016). This union proposes that the human-animal mind produces sensory metaphors which then take shape as language-specific units of selection that replicate and spread within or beyond the speech community (MacWhinney and O'Grady 2015; see also quote below). Thus, language as a complex system adapts to human cognition; and to the human social environment (Frank 2008: 237).

Historically the view arises from a Darwinian evolutionary conception which applies natural selection directly to language itself (Croft 2008). A language-organism analogy was per se commonplace in nineteenth century linguistics (Koerner 1978; Turner 2015), but it was August Schleicher who took the decisive step to break up with humanism, redefining cultural evolution as a natural science (Schleicher [1863] 1869):

Languages are organisms of nature; they have never been directed by the will of man; they rose, and developed themselves according to definite laws; they grew old, and died out. They, too, are subject to that series of phenomena

\footnotetext{
${ }^{2}$ It is sometimes claimed that Saussure banned historical-comparative linguistics (e.g. Aronoff 2017, p. 450). On the contrary, Course in General Linguistics explicitly states that the primary task of linguistics should be "to describe and trace the history of all observable languages, which amounts to tracing the history of families of languages and reconstructing as far as possible the mother language of each family" (Saussure [1916] 1959, p. 6).
} 
which we embrace under the name of "life." The science of language is consequently a natural science; its method is generally altogether the same as that of any other natural science. (Schleicher [1863] 1869: 20-21)

The method Schleicher refers to is the historical and reconstructive study of language groups as phylogenetic or family trees, equating languages with biological species. In his review of Schleicher, Max Müller (1870) adds a micro-level analogy of words as organisms to the macro-level analogy of languages as species. Darwin (1871) endorses both ideas asserting that

'A struggle for' life is constantly going on amongst the words and grammatical forms in each language. The better, the 'shorter, the easier forms are constantly gaining the' upper hand, and they owe their success to their own 'inherent virtue.' [...] the survival or preservation of certain favoured words in the struggle for existence is natural selection. (Darwin 1871: 60)

As the history then goes, the idea envisioned by the early Darwinists as languages and cultures competing for living space was adopted, after the authors' death, by the Nazi party from the writings of Schleicher's colleague Ernst Haeckel, with wellknown consequences (Richards 2002). Eventually, social Darwinism was banished from the humanities at the end of World War II (Aronoff 2017).

As the dust settled, Type 3 biological determinism made a comeback as sociobiology in the 1970s. This movement included Type 4 ideas, too, most famously Richard Dawkins's (1976) memetics which, from the point of linguistics, is rather similar to Müller's idea which is described by Darwin in his quote above. In the neoDarwinian model, words or ideas are considered as cultural replicators, something akin to genes or viruses (Dawkins 1995; Ritt 2004).

It seems likely that a historical chain from pre-1945 Darwinian linguists was broken, and that the current neo-Darwinian trend in linguistics has evolved independently of it. Following the popularity of Dawkins's (1976) nonfiction bestseller The Selfish Gene, and the obstacles faced by biolinguistics (Type 3), there has of lately been a true renaissance of the language-species analogy as materialised in a myriad of frameworks. Their assessment is not a completely simple task as is noted by Pelkey (2015).

Theorists who explore such analogies usually feel obliged to pin language to some specific sub-domain of biotic growth. William James selects "zoölogical evolution", William Croft prefers botanical evolution, but most theorists zoom in to more microbiotic levels - some claiming that linguistic phenomena are analogous to the cellular level and others arguing for the genetic level of biotic growth. For others, language is a parasite; for others still, language is a virus [...] What is more, some language theorists mix and match biological analogies at so many different levels that we are left with no clear theory of how these analogies function together. (Pelkey 2015: 103) 
Problems of applying biological principles to linguistics are discussed throughout the literature (but see Walkden 2012 for a brief introduction to the topic ${ }^{3}$ ). One pertinent question is whether languages are actually real and alive, or whether it is all a matter of a metaphor or an analogy. Interestingly enough, Schleicher had in his time countered criticism by explaining that he had not thought of languages as actually existing in reality (Koerner 1978, p. 32f).

One way for replicators to be real and thus an object of modern scientific study is if they are brain synapses whose behaviour and competition could be studied by electroencephalography (Aunger 2010; cf. 'mind reading' in a quote from MacWhinney and O'Grady 2015 below); but this is currently probably closer to an idea than an actual research program.

Croft (2008) rejects biological analogies as useless per se, and argues for a generalised mechanism of selection, echoing Dawkins's (1989, p. 322) concept of Universal Darwinism. Croft (2000) discusses his approach to language and evolution:

The third connection between language change and biological evolution is found where the theory of biological evolution itself has been adopted, or adapted, in order to construct an evolutionary theory of language change (see e.g. Keller 1994, pp. 141-152; McMahon 1994, pp. 314-340; Lass 1990, 1997; Ritt 2004). Evolution is recognized as a process that occurs with certain types of entities. The process is probably best understood as it occurs with populations of biological organisms; that is evolutionary biology. The hypothesis that forms the starting point of [Croft 2000] is that language change is an example of the same process, or a similar process, occurring with a different type of entity. (Croft 2000: 10

Which precise model of selection should be chosen is subject to debate. Croft (2000, 2006, 2008) argued specifically for an application of Hull's (1988) model of replication-rather than Dawkins's. But his proposal appears not to have found sufficiently widespread following despite criticism received by memetics (e.g. Polichak 2002). ${ }^{4}$ Both models were eventually placed under a common banner of Complex Adaptive Systems (Beckner et al. 2009), something which is explained as constituting a "reformulation of memetics" (Frank 2008).

What is common with various Type 4 theories is that they define themselves in opposition to Chomsky's innate universal grammar, although there is ambiguity in the terminology. For instance, Chomsky (2015) considers his approach as "emergent", which makes sense because language, in his conception, emerges from a random gene mutation. Nonetheless, it is more common to group various Type 4 approaches under the banner of emergentism; or "functionalism" (MacWhinney and O'Grady 2015) although the latter term is traditionally associated with the Prague school (Type 2).

Some of the most influential frameworks linked with this evolutionary, emergentist, functionalist programme include usage-based linguistics (Bybee and Hopper

\footnotetext{
${ }^{3}$ Walkden (2012) is a slide presentation which currently appears to provide the most comprehensive critical review of the literature.

4 To briefly summarise the criticism, it is argued that the science of genetics breaks down to a weak metaphor when transferred to social sciences (Vada 2015).
} 
2001) and construction grammar (Goldberg 2006). Lakoff's cognitive linguistics and conceptual metaphor theory are also associated with it. As MacWhinney and O’Grady (ibid.) explain,

Faced with this embarrassment of theoretical riches, students often ask what is the relation between Emergentism and all these other approaches. The answer is that all of these approaches fall under the general category of Emergentism, because all recognize the importance of the principles of competition, hierarchicality, and timeframes [...] Where these approaches differ is in terms of their emphases. For example, given a metaphor such as choking poverty, Embodied Cognition emphasizes mappings of this metaphor to the source domain of the body, Mind-Reading highlights ways in which this metaphor activates particular areas of the brain, usage-based analysis focuses on the conventionalization of the metaphor through usage, and memetics examines the spread of the metaphor across communities. (MacWhinney and O'Grady 2015: 9)

Like meme and replicator, construction is another name for the basic unit of selection. A construction is a form-meaning pair which can be a morpheme, a word or a phrase: a construction can consist of several smaller units (Goldberg ibid.). This idea reiterates Dawkins's (1989, p. 195) concept of meme complexes as "units within units". There is indeed a dispute between memeticists and those who advocate other models of linguistic evolution. Christiansen and Chater (2008) argue that usagebased linguistics, construction grammar and complex adaptive systems are different from memetics, but Blackmore (2008) demonstrates that same ideas have been published in memetics literature.

The Schleicherian study of language as phylogenetic trees has also seen its revival, as computational methods are borrowed from evolutionary biology (Atkinson and Gray 2005). Lastly, a new model is provided by the evolutionary study of natural constructions such as the nests of social insects. The "social" construction of language is compared to emergent principles which create termites' nests, for instance (Dahl 2004).

\section{An assessment of theories of language}

Different theories of language reflect different aspects of language by placing the major source of explanans of the language phenomenon in different loci: Type 1 in social history, Type 2 in the semiotic system, Type 3 in human biology, and Type 4 in the evolutionary workings of the language organism or population.

None of the approaches appears to provide a complete definition of language. For a criticism, starting from Type 2: Hjelmslev ([1943] 1953) offers a most detailed description of the language system. What is noticeable in his definition of 'language' is that he does not consider it as an essentially social and historical phenomenon. Thus, his conception of language was described as an "abstract object" in "Type 2: humanistic-systemic" section. Hjelmslev implies that there is an algebraic system underlying all languages. It is an interesting position, but the relationship between 
individual languages, such as English and Japanese, and the algebraic language device is not fully expounded.

As a transformation of Hjelmslev, Type 3 generative grammar also considers 'language' or 'grammar' algebraic. What people commonly perceive as languages are mere epiphenomena caused by universal grammar (Hassler 2018). This could be understood as meaning that natural grammars are formal grammars generated by an innate computational mechanism. The full explanation has however undergone many reforms, and in the current version (Hauser, Chomsky and Fitch 2002) only recursion remains part of grammar. Differences between languages are now explained primarily in terms of lexical parameters rather than grammatical ones (Christiansen and Chater 2008). The innate element is suggested to provide a choice of possible structures for natural languages (cf. Newmeyer 2005). At this point, though, if lexical parameters are not considered innate, the role of the human language faculty has reduced so dramatically it could be largely disposed of, whereby the generative enterprise might collapse back into pre-Chomskyan Type 1.

This does not necessarily mean a return to behaviourism. Wundt's concept of language represented mentalist psychology (Levelt 1992); and Roman Jakobson advocated a (Type 2) view of linguistics as a "cognitive science" (Garvin 1953) long before Chomsky.

The Dawkinsian concept of Type 4 sees language as a kind of virus which has mutated into billions of strains which have spread globally and across linguistic borders. So what exactly are what we perceive as languages? The complex adaptive systems position remains critical of Type 1,2 and 3; but its own definition is so broad it is difficult to scrutinise. The current formulation (Beckner et al. 2009) resembles in some ways brainstorming more than the kind of definition of language that is needed for a scientific linguistics.

This could be found more easily in Type 1, which today lacks a polestar; but there is something to be learned from the history of theoretical linguistics. A fundamental problem was recognised by 19th-century Sanskritists like Saussure (Aronoff 2017). At a certain point historical explanation tends to be reduced to mere speculations about the origin of language. This is due to incompleteness of available data and reliability limitations of the comparative-reconstructive method. A related philosophical problem is hinted at by Max Müller's taxonomy of classical speculations including the likes of the 'bow wow' theory, the 'pooh-pooh' theory and other conjectures about the origin of words: whether they arise from grunts, chants, mating calls, imitations of natural sounds, etc. (Noiré 1879).

If we had a time machine that took us through all the stages of lexical development to the very beginnings of human language, and we learned that the first ever word used for egg, for example, was actually 'bow wow': would that not explain everything and nothing about language at the same time? This problem makes Saussure's proposal of complementing historical linguistics with a systemic explanation tempting.

As regards the topic of the theory of language in general, its influence has been impressive. Linguistics has many times been taken as a guiding light for other sciences. It has provided models of social and cultural construction perhaps due to the 
systematic nature of grammar. Theorising about language has nonetheless remained on a philosophical level: the presented frameworks have not found unequivocal scientific evidence for their most ambitious hypotheses.

But there is something potentially interesting in the literature. Labov's (1994) conclusion concerning language change studies is that the mechanism responsible for the preservation of economy of the system is quite different from what the functional structuralists had suggested (cf. presentation of Martinet in "Type 1: humanistic-historical" section):

Such a mechanism is the reverse of the effect envisaged by functional theories in linguistics. Kroch's argument indicates that it is not the desire to be understood, but rather the consequence of misunderstanding that influences language change. This mechanism implies a mismatch between producer and interpreter: the type of built-in instability that we would expect to find behind long-term shifts in language behavior. (Labov 1994: 586)

Instead of striving for greater clarity, a new generation of speakers performs a reanalysis by removing old forms which, after the introduction of new ones, have begun to cause misunderstanding. But Verleyen (2006) points out that Labov's definition of functionalism is particularly narrow, effectively referring to the preservation of already established distinctions.

Whether promoting disambiguation where phonetic changes occur, or abandoning items that have become ambiguous as a more distant side effect of the changes, either way would seem to explain why no matter how much functional decay languages undergo throughout the centuries, they do not become more and more difficult to understand for the native speaker. Since the two arguments are logically equivalent, ${ }^{5}$ though, it might be the case that language change research has already found scientific evidence for the semiotic approach. That is, language as a system whose structures emerge from the needs of meaning expression.

\section{End discussion}

This paper proposed a fourfold table to explain the main differences between modern schools of linguistic thought by investigating how ideologies behind them are linked with intellectual history. While the humanistic side seems to fall quite naturally into the taxonomy, there is a curious mismatch with biological linguistics that requires some clarification.

In this taxonomy, generative grammar, which entails a focus on synchronic analysis, is placed into the historical Type 3; while construction grammar, for example, which yields itself more readily to a historical analysis (Hurford 2012, pp. 176-177), is placed among Type 4 systemic views.

\footnotetext{
${ }^{5}$ per double negation, and as such, either statement may be removed. A system can strive for more clarity by adding heteronymy or by removing non-heteronymy; but the latter is equivalent to the former in the given context where it means avoiding the increase of ambiguous expressions.
} 
The reason for this is because schools of thought can be classified on different grounds. Since the topic here is theories of language, the question is how each school of thought perceives the nature of language. For generative grammar, linguistic structures are genetically based. Since it is not assumed that our genetic makeup is changing, synchronic analysis is the logical way to examine such static structures.

Conversely, systemic Type 4 considers language as a balanced system-in so far as ecological systems tend to become balanced in the long run-but yields itself to historical analysis. This is not contradictory because Type 4 does not postulate genetic changes for linguistic change. Instead, diachronic changes are considered systemic ones.

Of course, authors do combine ideas from different aspects; but it seems that the major differences between the most influential linguistics frameworks are rather naturally explained by a classification based on the two axes proposed here: humanistic versus biological, and historical versus systemic.

Where ideas blend, the taxonomy can be useful for pointing out what kind of synthesis is being made, and what kind of problems there might arise. To take some examples, M. A. K. Halliday's Systemic Functional Linguistics (SFL) derives from Prague structural linguistics and is therefore considered a Type 2 humanistic approach. However, M. A. K. Halliday (1925-2018) endorsed memetics (cf. Type 4) in his later years (e.g. Halliday and Webster 2009, p. 174; Halliday and Matthiessen 2014, p. 33). That position is now controversial: François (2018) argues that the semiotic-systemic view of SFL is too different from the "external" systemic functionalism of authors that in the present paper fall towards Type 4 biological-systemic (Du Bois 1985; Hopper 1987; Langacker 2008; Lakoff 1987; Croft and Cruse 2004).

As mentioned above, though, Lakoff's Cognitive Linguistics which offers a natural historical explanation of human language ability (Type 3), is united with Type 4 approaches (see "Type 4: Biological-systemic" section for discussion). It is argued that the motivation behind this alliance is to raise forces against Chomsky's Type 3 approach which has dominated American linguistics (Peeters 2001).

Some views are eclectic or fall between major types. Some examples discussed in the literature include Givón (1979) who is labelled as "controversial" by Nichols (1984) because Givón combines features that could be identified as representing Type 2 or Type 4 .

Croft (2008) considers Blevins (2004) as eccentric to evolutionary linguistics because Blevins makes explicit that the Darwinian reference in her work is purely metaphorical. Since the line between humanistic and biological or biotic linguistics is traditionally drawn between the advocates and the opponents of Darwinian linguistics (Sériot 1999), it is not easy to find a place for Blevins within the main schools of linguistic thought.

As pointed out in "Sociobiological or Darwinian evolutionary linguistics" section, evolution as a concept is ambiguous. Many of the American descriptivists from the Boasian and Bloomfieldian school advocated a version of evolutionary linguistics. In fact, Bloomfield (1914) himself was in favour of Wundt's gestural theory: a rejection of Darwin (Richards 1980, p. 58). Boas for his part developed a multilinear theory of evolution (Adams 1955). It is likewise important to notice that, although Charles Hockett's design features of language evolution have more recently raised 
interest in the Darwinian camps, it is not compatible with them due to Hockett's ontology of language as a cultural product (Wacewicz and Żywiczyński 2015).

Croft (2002, p. 6) considers Joseph Greenberg (1915-2001) and typology in general as representative of Croft's view of biological linguistics. However, it is difficult to find evidence that Greenberg advocated an evolutionary model of replication and selection. He (see especially Greenberg 1992) was interested in evolutionary anthropology, but concludes:

What is rescuable [of Schleicher's organicism] is that linguistics is an empirical science and that therefore its methodology is essentially that of all sciences, whether social or natural. (Greenberg 1992: 140)

It seems natural to place Hockett and Greenberg into Type 1 with Boas, Sapir, Bloomfield, Whorf and others from the same school of American descriptivism.

Although finding the right place for all authors is not a simple task, the systematics presented in this paper will hopefully help identify and give terms to problematics or anomalies. It could also prove to be useful for further philosophical investigations.

There are, for example, indications that these different types of linguistics have each developed their own general epistemology. Furthermore, functional explanation has been used in different ways; to gain further insight into the problematics, one needs to first identify which theory of language each given argument is building up. It has also been an implicit suggestion of this paper that schools of social sciences are organised along the same lines as linguistics. Whether such an idea is correct, and in what exact way social and linguistic theory are analogous will be the matter of another investigation.

Funding Open access funding provided by University of Helsinki including Helsinki University Central Hospital.

\section{Compliance with ethical standards}

Data availability All data analysed are included in the paper.

Conflict of interest The authors declared that they have no conflict of interest.

Open Access This article is licensed under a Creative Commons Attribution 4.0 International License, which permits use, sharing, adaptation, distribution and reproduction in any medium or format, as long as you give appropriate credit to the original author(s) and the source, provide a link to the Creative Commons licence, and indicate if changes were made. The images or other third party material in this article are included in the article's Creative Commons licence, unless indicated otherwise in a credit line to the material. If material is not included in the article's Creative Commons licence and your intended use is not permitted by statutory regulation or exceeds the permitted use, you will need to obtain permission directly from the copyright holder. To view a copy of this licence, visit http://creativecommons.org/licen ses/by/4.0/. 


\section{References}

Adams RM (1955) Theory of culture change: the methodology of multilinear evolution. University of Illinois Press, Urbana

Arnauld A, Lancelot C ([1660] 2015) General and rational grammar: the port-royal grammar. Walter de Gruyter, Berlin

Aronoff M (2017) Darwinism tested by the science of language. In: Bowern C, Horn L, Zanuttini R (eds) On Looking into Words (and Beyond): Structures, Relations, Analyses. SUNY Press, Albany

Atkinson QD, Gray RD (2005) Curious parallels and curious connections - phylogenetic thinking in biology and historical linguistics. Syst Biol 54(4):513-526. https://doi.org/10.1080/106351505909503 17

Aunger R (2010) The electric meme: a new theory of how we think. Free Press, Glencoe IL

Beckner C, Blythe R, Bybee J, Christiansen MH, Croft W, Ellis NC, Holland J, Ke J, Larsen-Freeman ST (2009) Language is a complex adaptive system: position paper. Lang Learn 59:1-26. https://doi.org /10.1111/j.1467-9922.2009.00533.x

Berwick RC, Chomsky N (2016) Why Only Us: Language and Evolution. MIT Press, Cambridge MA

Blackmore S (2008) Memes shape brains shape memes. Behav Brain Sci 31(5):513-513. https://doi. org/10.1017/S0140525X08005037

Blevins J (2004) Evolutionary phonology: the emergence of sound patterns. Cambridge University Press, Cambridge

Bloomfield L (1914) An introduction to the study of language. Henry Holt Co, New York

Bloomfield L (1933) Language. George Allen Unwin, London

Bopp F (1816) Über das Conjugationssystem der Sanskritsprache in Vergleichung mit jenem der griechischen, lateinischen, persischen und germanischen Sprache. Nebst Episoden aus dem Ramajana und Mahabharata in genauen metrischen Übersetzungen aus dem Originaltexte und ei. M. Andreäsche Buchhandlung, Frankfurt

Butler CS (2003) Structure and function: a guide to three major structural-functional theories, Part I. Approaches to the simplex clause. John Benjamins, Amsterdam

Bybee JL, Hopper P (2001) Frequency and the emergence of linguistic structure. John Benjamins, Amsterdam

Chomsky N (1965) Aspects of the theory of syntax. MIT Press, Cambridge

Chomsky N (2000) The architecture of language. Oxford University Press, Oxford

Chomsky N (2015) The minimalist program (20th anniv). MIT Press, Cambridge

Chomsky N, McGilvray J (2012) The science of language: interviews with James McGilvray. Cambridge University Press, Cambridge

Christiansen MH, Chater N (2008) Language as shaped by the brain. Behav Brain Sci 31(5):489-509. https://doi.org/10.1017/S0140525X08004998

Cooper JM, Hutchinson DS (eds) (1997) Plato: complete works. Hackett, Indianapolis

Corning PA (1982) Durkheim and Spencer. Br J Sociol 33(3):359-382. https://doi.org/10.2307/589482

Croft W (1995) Autonomy and functionalist linguistics. Language 71(3):490. https://doi. org/10.2307/416218

Croft W (2000) Explaining language change: an evolutionary approach. Pearson Education, New York

Croft W (2002) Typology and universals, 2nd edn. Cambridge University Press, Cambridge

Croft W (2006) The relevance of an evolutionary model to historical linguistics. In: Thomsen ON (ed) Competing models of linguistic change. John Benjamins, Amsterdam, pp 91-132. https://doi. org/10.1075/cilt.279.08cro

Croft W (2008) Evolutionary linguistics. Annu Rev Anthropol 37(1):219-234. https://doi.org/10.1146/ annurev.anthro.37.081407.085156

Croft W (2015) Functional approaches to grammar. In: Smelser NJ, Baltes PB (eds) International encyclopedia of the social behavioral sciences. Elsevier, Amsterdam, pp 470-475. https://doi. org/10.1016/B978-0-08-097086-8.53009-8

Croft W (2016) Typology and the future of cognitive linguistics. Cogn Linguist 27(4):587-602. https:// doi.org/10.1515/cog-2016-0056

Croft W, Cruse A (2004) Cognitive linguistics. Cambridge University Press, Cambridge

Dahl Ö (2004) The growth and maintenance of linguistic complexity. John Benjamins, Amsterdam

Dalgarno G ([1661] 1974) Ars Signorum, vulgo Character Universalis et Lingua Philosophica. Scolar Press, London. 
Daneš F (1987) On Prague school functionalism in linguistics. In: Dirven R (ed) functionalism in linguistics. John Benjamins, Amsterdam

Danesi M (1993) Vico, metaphor, and the origin of language. Indiana University Press, Bloomington

Darwin C (1859) On the origin of species by means of natural selection. Murray, London

Darwin C (1871) The descent of man, and selection in relation to sex. Murray, London

Dawkins R (1976) The Selfish Gene. Oxford University Press, Oxford

Dawkins R (1989) The selfish gene, 2nd edn. Oxford University Press, Oxford

Dawkins R (1995) Viruses of the mind. In: Dahlbom B (ed) Dennett and his critics—demystifying mind. Wiley, Hoboken

de Bot K (2015) A history of applied linguistics: from 1980 to the present. Routledge, Abingdon-on-Thames

Derrida J ([1967] 1998) Of grammatology, corr edn. The Johns Hopkins University Press, Baltimore

Dosse F (1997a) History of structuralism, vol 1: the rising sign, 1945-1966. University of Minnesota Press, Minneapolis

Dosse F (1997b) History of structuralism, vol 2: the sign sets, 1967-present. University of Minnesota Press, Minneapolis

Druart T-A (2019) al-Farabi. In: Zalta EN (ed) stanford encyclopedia of philosophy, Winter edn. Stanford University, Stanford. Retrieved from https://plato.stanford.edu/archives/fall2020/entries/al-farabi

Du Bois JW (1985) Competing motivations. In: Haiman J (ed) Iconicity in syntax. John Benjamins, Amsterdam, pp 343-366

Ehrlich P, Feldman M (2003) Genes and cultures. Curr Anthropol 44(1):87-107. https://doi. org/10.1086/344470

Ehrlich S, Meyerhoff M, Holmes J (eds) (2014) The handbook of language, gender, and sexuality, 2nd edn. Wiley, Malden

Enfield NJ (2013) Language, culture, and mind: trends and standards in the latest pendulum swing. J R Anthropol Inst 19(1):155-169. https://doi.org/10.1111/1467-9655.12008

Evans B, Bowern C (eds) (2015) The Routledge handbook of historical linguistics. Routledge, London

Everett DL (2012) Language: the cultural tool. Pantheon Books, New York

Feldman J (2007) Framing the debate: famous presidential speeches and how progressives can use them to change the conversation (and win election), with an introduction by George Lakoff. Ig Publishing, New York

Fernald A, Marchman VA (2006) Language learning in infancy. In: Traxler M, Gernsbacher M (eds) Handbook of psycholinguistics, 2nd edn. Academic Press, Cambridge, pp 1027-1071

Fitch WT (2010) The evolution of language. Cambridge University Press, Cambridge

François J (2018) The stance of systemic functional linguistics amongst functional(ist) theories of language and its "Systemic Purpose." In: Sellami-Baklouti A, Fontaine L (eds) Perspectives from systemic functional linguistics. Routledge, New York, pp 6-25

Frank RM (2008) The language-organism-species analogy: a complex adaptive systems approach to shifting perspectives on "language." In Sociocultural situatedness, vol 2. De Gruyter, Berlin, pp 215-262

Garvin PL (1953) Review of preliminaries to speech analysis by Jakobson, Gunnar. Fant and Halle Language 29(4):472-481. https://doi.org/10.2307/409957

Garvin PL (1954) Reviewed work: Prolegomena to a theory of language by Louis Hjelmslev, translated by Francis. J Whitfield Language 30(1):69. https://doi.org/10.2307/410221

Givón T (1979) On understanding grammar. Academic Press, New York

Goldberg A (2006) Constructions at work: the nature of generalization in language. Oxford University Press, Oxford

Greenberg JH (1992) Preliminaries to a systematic comparison between biological and linguistic evolution. In: Gell-Mann M, Hawkins JA (eds) The evolution of human languages. Addison-Wesley, Redwood City

Halliday MAK, Matthiessen CMIM (2014) Halliday's introduction to functional grammar, 4th edn. Routledge, New York

Halliday MAK, Webster JJ (2009) Continuum companion to systemic functional linguistics. Continuum, New York

Hamans CSJN, Seuren PAM (2010) Chomsky in search of a pedigree. In: Kibbee DA (ed) Chomskyan (r) evolutions. John Benjamins, Amsterdam, pp 377-394. https://doi.org/10.1075/z.154.14ham

Hassler G (2018) Linguistic relativity and language as epiphenomenon: two contradictory positions. Confluência: Revista Do Instituto de Língua Portuguesa 55:82-98 
Hauser MD, Chomsky N, Fitch WT (2002) The faculty of language: what is it, who has it, and how did it evolve? Science 298(5598):1569-1579. https://doi.org/10.1126/science.298.5598.1569

Hawkins JA (2004) Efficiency and complexity in Grammars. Oxford University Press, Oxford

Hegel GWF (1807) Phänomenologie des Geistes. Joseph Anton Goebhardt, Bamberg

Hejl PM (1995) The importance of the concepts of “organism" and "evolution" in Emile Durkheim's division of social labor and the influence of Herbert Spencer. In: Maasen S, Mendelsohn E, Weingart P (eds) Biology as society, society as biology: metaphors. Springer, Dordrecht, pp 155-191. https://doi.org/10.1007/978-94-011-0673-3_8

Hjelmslev L ([1943] 1953) Prolegomena to a theory of language (translated). Indiana University Press, Baltimore.

Hobbes T ([1651] 2010) Leviathan, rev edn. Broadview Press, Peterborough

Hopper P (1987) Emergent grammar. Proceedings of the Thirteenth Annual Meeting of the Berkeley Linguistics Society. https://doi.org/10.3765/bls.v13i0.1834

Hull D (1988) Science as process. University of Chicago Press, Chicago

Hurford JR (2012) The origins of grammar. Oxford University Press, Oxford

Itkonen E (1999) Functionalism yes, biologism no. Zeitschrift Für Sprachwissenschaft 18(2):219-221. https://doi.org/10.1515/zfsw.1999.18.2.219

Itkonen E (2011) On Coseriu's legacy. Energeia III:1-29

Itkonen E (2013) On explanation in linguistics. Energeia V:10-40

Itkonen E (2013) Philosophy of linguistics. In: Allan K (ed) The Oxford handbook of the history of linguistics. Oxford University Press, Oxford. https://doi.org/10.1093/oxfordhb/9780199585 847.013.0035

Jermołowicz R (2003) On the project of a universal language in the framework of the XVII century philosophy. Stud Logic Grammar Rhetoric 6(19):51-61

Johnston WD (1922) The evolution of tools and implements. Am Midl Nat 8(2):49-60

Joseph JE (2002) From Whitney to Chomsky: essays in the history of American linguistics. John Benjamins, Amsterdam

Keller R (1994) On language change: the invisible hand in language. CRC Press, Boca Raton, FL

Kiparsky P (2009) On the architecture of Pāṇini's grammar. In: Huet G, Kulkarni A, Scharf P (eds) Sanskrit computational linguistics. ISCLS 2007, ISCLS 2008. Lecture notes in computer science, vol 5402. Springer, Berlin. https://doi.org/10.1007/978-3-642-00155-0_2

Klautke E (2010) The mind of the nation: the debate about Völkerpsychologie, 1851-1900. Cent Europe 8(1):1-19. https://doi.org/10.1179/174582110X12676382921428

Koerner EFK (1978) Toward a historiography of linguistics: selected essays. John Benjamins, Amsterdam/Philadelphia

Koerner EFK (1992) The Sapir-Whorf hypothesis: a preliminary history and a bibiographical essay. J Linguist Anthropol 2(2):173-198. https://doi.org/10.2307/43102168

Koster J (2009) Ceaseless, unpredictable creativity. Biolinguistics 3(1):61-92

Labov W (1994) Principles of linguistic change, vol I: internal factors. Blackwell, Oxford

Lakoff G (1987) Women, fire, and dangerous things: what categories reveal about the mind. Chicago University Press, Chicago

Lakoff G (1990) The invariance hypothesis: is abstract reason based on image-schemas? Cogn Linguist 1(1):39-74. https://doi.org/10.1515/cogl.1990.1.1.39

Lakoff G, Johnson M (1999) Philosophy in the flesh: the embodied mind and its challenge to western thought. Basic Books, New York

Langacker R (2008) A basic introduction to cognitive grammar. Cambridge University Press, Cambridge

Lass R (1990) How to do things with junk: exaptation in language evolution. J Linguist 26(1):79-102

Lass R (1997) Historical linguistics and language change. Cambridge University Press, Cambridge

Lehmann C (2016) Grammaticalization in Bopp. Veleia 33:103-112. https://doi.org/10.1387/velei a. 16825

Levelt WJM (1992) Psycholinguistics: an overview. In: Bright W (ed) International encyclopedia of linguistics. Oxford University Press, Oxford, pp 290-294

Long AA (1982) Soul and body in stoicism. Phronesis 27(1-2):34-57. https://doi.org/10.1163/15685 2882 X00032

Macnamara J (2009) Through the rearview mirror: historical reflections on psychology. MIT Press, Cambridge

MacWhinney B, O'Grady W (2015) Introduction. In: MacWhinney B, O'Grady W (eds) Handbook of language emergence. Wiley, Hoboken 
Mandeville B (1705) The grumbling hive: or, Knaves Turn'd Honest. Sam Ballard, London

Markie P (2017) Rationalism vs. empiricism. In: Zalta EN (ed) Stanford encyclopedia of philosophy, Fall edn. Stanford University, Stanford. Retrieved from https://plato.stanford.edu/archives/fall2017/entri es/rationalism-empiricism. Accessed 19 Jan 2021

Mathison J, Tosey P (2009) Exploring moments of knowing: NLP and enquiry into inner landscapes. J Conscious Stud 16(10-11):189-216

McMahon A (1994) Understanding language change. Cambridge University Press, Cambridge

McElhinny B (2015) Language and political economy. In: Bonvillain N (ed) The Routledge handbook of linguistic anthropology. Routledge, London, pp 279-300

Mueller-Vollmer K, Messling M (2017) Wilhelm von Humboldt. In: Zalta EN (ed) Stanford encyclopedia of philosophy, Winter edn. Stanford University, Stanford. Retrieved from https://plato.stanford.edu/ entries/wilhelm-humboldt. Accessed 19 Jan 2021

Müller M (1870) Darwinism tested by the science of language. translated from the German of Professor August Schleicher. Nature 1(10):256-259. https://doi.org/10.1038/001256a0

Newmeyer F (2005) Possible and probable languages: a generative perspective on linguistic typology. Oxford University Press, Oxford

Nichols J (1984) Functional theories of grammar. Annu Rev Anthropol 13(1):97-117. https://doi. org/10.1146/annurev.an.13.100184.000525

Nichols SG (2012) Global language or universal language? From Babel to the illustrious vernacular. Digit Philol J Medieval Cultures 1(1):73-109. https://doi.org/10.1353/dph.2012.0004

Noiré L (1879) Max Müller and the philosophy of language. Longmans, Green, and Co, London

Nöth W (1995) Handbook of semiotics. Indiana University Press, Bloomington

Osborne T, Kahane S (2015) Translators' introduction. In Elements of structural syntax by Lucien Tesnière. John Benjamins, Amsterdam/Philadelphia, pp xxix-lxxii.

Peeters B (2001) Does cognitive linguistics live up to its name? In: Dirven R, Hawkins B, Sandikcioblu E (eds) Language and ideology, vol 1: theoretical cognitive approaches. John Benjamins, Amsterdam, pp 83-106. https://doi.org/10.1075/cilt.204.04pee

Pelkey J (2015) Deep congruence between linguistic and biotic growth: evidence for semiotic foundations. In: Velmezova E, Kull K, Cowley SJ (eds) Biosemiotic perspectives on language and linguistics. Springer, Cham, pp 97-119. https://doi.org/10.1007/978-3-319-20663-9_6

Pinker S (1994) The language instinct: the new science of language and mind. HarperCollins, New York

Polichak JW (2002) Memes as pseudoscience. In: Shermer M, Linse P (eds) Skeptic encyclopedia of pseudoscience. ABC Clio, Santa Barbara, pp 664-677

Popov I (2008) Orthogenesis versus Darwinism: the Russian case. Revue d'histoire Des Sciences 61(2):367-397. https://doi.org/10.3917/rhs.612.0367

Pourciau SM (2017) The writing of spirit: soul, system, and the roots of language science. Fordham University Press, New York

Richards RJ (1980) Wundt's early theories of unconscious inference and cognitive evolution in their relation to Darwinian biopsychology. In: Bringmann WG, Tweney RD (eds) Wundt studies: a centennial collection. C. J. Hogrefe, Toronto, pp 42-70

Richards RJ (2002) The linguistic creation of man: Charles Darwin, August Schleicher, Ernst Haeckel, and the missing link in nineteenth-century evolutionary theory. In: Dörries M (ed) Experimenting in tongues. Stanford University Press, Stanford, pp 21-48

Richerson PJ, Boyd R (2010) Why possibly language evolved. Biolinguistics 4(2-3):289-306

Ritt N (2004) Selfish sounds and linguistic evolution: a Darwinian approach to language change. Cambridge University Press, Cambridge

Sampson G (1980) Schools of Linguistics. Hutchinson, London

Saussure F de ([1916] 1959) Course in general linguistics. Philosophy Library, New York

Schleicher A ([1863] 1869) Darwinism tested by the science of language (translated). John Camden Hoten, London

Scholz BC, Pelletier FJ, Pullum GK (2020) Philosophy of linguistics. In: Zalta EN (ed) Stanford encyclopedia of philosophy, Summer edn. Stanford University, Stanford. Retrieved from https://plato.stanf ord.edu/archives/sum2020/entries/linguistics. Accessed 19 Jan 2021

Sériot P (1999) The impact of Czech and Russian biology on the linguistic thought of the Prague linguistic circle. In: Hajičová E, Hoskovec T, Leška O, Sgall P (eds) Prague Linguistic Circle Papers, vol 3. John Benjamins, Amsterdam

Seuren PAM (1998) Western linguistics: an historical introduction. Blackwell, Hoboken 
Seuren PAM (2006) Early formalization tendencies in 20th-century American linguistics. In: Auroux S, Koerner EFK, Niederehe HJ, Versteegh K (eds) History of the language sciences: an international handbook on the evolution of the study of language from the beginnings to the present. Walter de Gruyter, Berlin, pp 2026-2034

Smith N (2002) Chomsky: ideas and ideals. Cambridge University Press, Cambridge

Song JJ (2010) Word order typology. In: Song JJ (ed) The Oxford handbook of linguistic typology. Oxford University Press, Oxford, pp 253-279. https://doi.org/10.1093/oxfordhb/9780199281251.001.0001

Spiro ME (1986) Cultural relativism and the future of anthropology. Cult Anthropol 1(3):259-286. https ://doi.org/10.1525/can.1986.1.3.02a00010

Turner J (2015) Philology: the forgotten origins of the modern humanities. Princeton University Press, Princeton

Vada $\varnothing$ (2015) What happened to memetics. Emergence: complexity and organization, September 30. Retrieved from https://journal.emergentpublications.com/article/what-happened-to-memetics/. Accessed 19 Jan 2021

Verheggen T (1996) Durkheim's respresentations considered as Vorstellungen. Curr Perspect Soc Theory 16:189-220

Verleyen S (2006) L'abandon progressif du fonctionnalisme dans les travaux de William Labov. Historiogr Linguist 33(3):335-355. https://doi.org/10.1075/hl.33.3.04ver

Verlinsky A (2005) Epicurus and his predecessors on the origin of language. In Language and learning. Cambridge University Press, Cambridge, pp 56-100. https://doi.org/10.1017/CBO978051148252 6.005

Vicentini A (2003) The economy principle in language: notes and observations from Early Modern English grammars. Mots Words Palabras 3:37-57

von Humboldt W (1836) Über die Verschiedenheit des menschlichen Sprachbaues und ihren Einfluss auf die geistige Entwickelung des Menschengeschlechts. F. Dümmler, Berlin

Wacewicz S, Żywiczyński P (2015) Language evolution: why Hockett's design features are a non-starter. Biosemiotics 8(1):29-46. https://doi.org/10.1007/s12304-014-9203-2

Walkden G (2012) Why language change is not (language) evolution. Retrieved from http://walkd en.space/Walkden_2012_evo.pdf. Accessed 19 Jan 2021

Wells RS (1947) Immediate constituents. Language 23(2):81. https://doi.org/10.2307/410382

Whitney WD (1875) The life and growth of language. H. S. King, London

Williams J (2005) Understanding poststructuralism. Cambridge University Press, Cambridge

Wolloch N (2011) The civilizing process, nature, and stadial theory. Eighteenth Cent Stud 44(2):245-259

Wundt W (1880) Logik: eine Untersuchung der Principien der Erkenntniss und der Methoden wissenschaftlicher Forschung, vol 1. Enke, Stuttgart

Wundt W (1889) Über die Einteilung der Wissenschaften (On the division of the sciences). Philos Stud $5: 1-55$ 